British Journal of Education (BJE)

Vol. 8, Issue 5, pp. 40-57, May 2020

Published by ECRTD- UK

Print ISSN: ISSN 2054-6351: Online ISSN: ISSN 2054-636X

\title{
THE FOUR-TYPE NEGOTIATION MATRIX: A MODEL FOR ASSESSING NEGOTIATION PROCESSES
}

\author{
Dr Murillo de Oliveira Dias
}

Fundação Getulio Vargas, Brazil

Corresponding author: Praia de Botafogo 190, Rio de Janeiro, Brazil, ZIP Code 22250900

\begin{abstract}
A model of the negotiation process is developed and applied to a sample of negotiation cases through qualitative meta-analysis. Key findings revealed a two-dimensional matrix comprising the entire negotiation process, and suggest that value creation strategies should be used for both parties in such transactions to achieve mutual benefits. This article is intended to provide scholars with a new perspective and taxonomy on the negotiation dimensions, and implications of these findings for managerial practice are discussed.
\end{abstract}

KEYWORDS: negotiation dimensions; four-type negotiation matrix

\section{INTRODUCTION}

Research on negotiation has attracted scholars' attention as conceptual development has evolved regarding parties and issues negotiated. This paper proposes an investigation on the following negotiations: (i) two-parties, one issue; (ii) two-parties; multiple issues; (iii) multiple-parties, one issue, and (iv) multiple parties, multiple issues (Raiffa, 1982; Fisher Ury and Patton, 1981; Sebenius, 1992; Ury, 2015; Susskind \& Field, 1996; Salacuse, 2008; Susskind \& Cruikshank, 1987; Dias, M, 2019). The purpose of this article is to develop and test a qualitative two-dimensional negotiation matrix. The importance of such models on negotiation has been emphasized by Elfenbein (2013). Development of the matrix is based on meta-analysis that examined $\mathrm{N}=50$ negotiation cases, from retail buyer-seller, two-party, one issue negotiation until Aerospatiale, multi-party, multi-issue negotiation. The matrix was tested in another set of negotiation cases, which examined several components of the negotiation dimensions. The findings provide scholars, managers, negotiators, mediators, facilitators, teachers, and practitioners, in general, a new insight into the two-dimensional aspects of the negotiation process.

Some of the most relevant past conceptual groundworks for the negotiation process are presented in Figures 1-3. Observe in Figure 1 that all types of negotiations are encompassed into four dimensions 
British Journal of Education (BJE)

Vol. 8, Issue 5, pp. 40-57, May 2020

Published by ECRTD- UK

Print ISSN: ISSN 2054-6351: Online ISSN: ISSN 2054-636X

(Olekalns \& Adair, 2013b): (i) individual processes; (ii) social-psychological processes; (iii) communication processes, and (iv) complex negotiation.

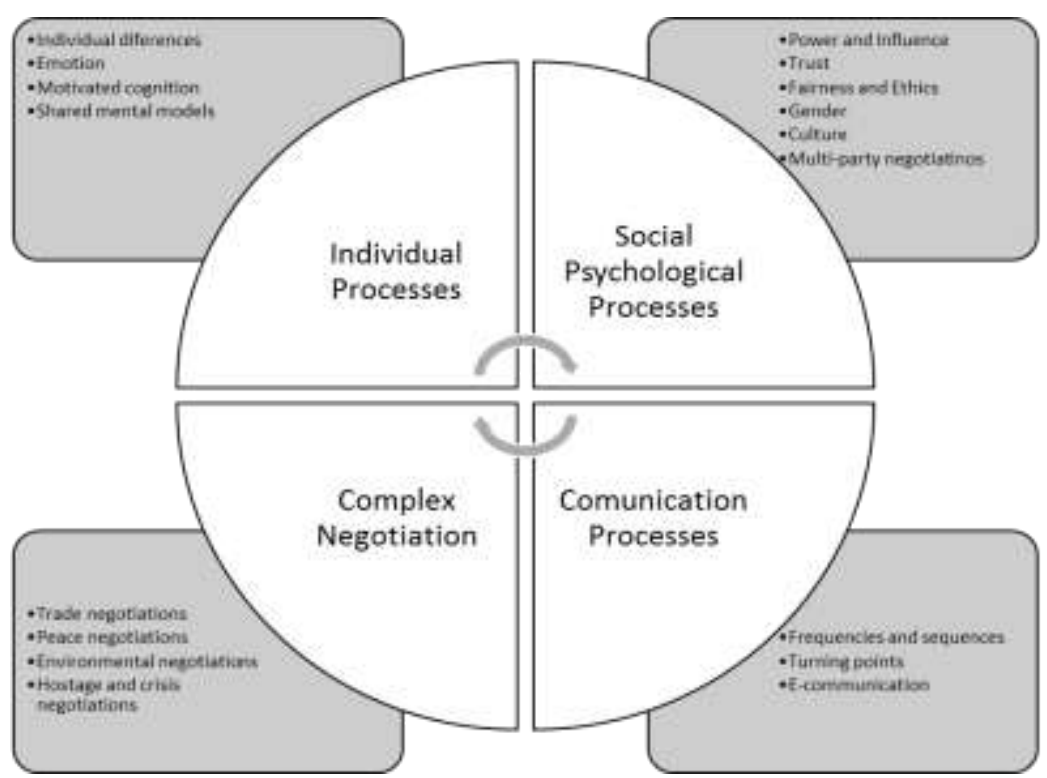

Figure 1. The four perspectives of the Negotiation Process. Adapted from Olekalns \& Adair, $2013 b$.

Figure 2 and 3 illustrate the managerial grid (Blake and Mouton, 1964), and the Dual concern model (Pruitt \& Rubin, 1986), respectively:

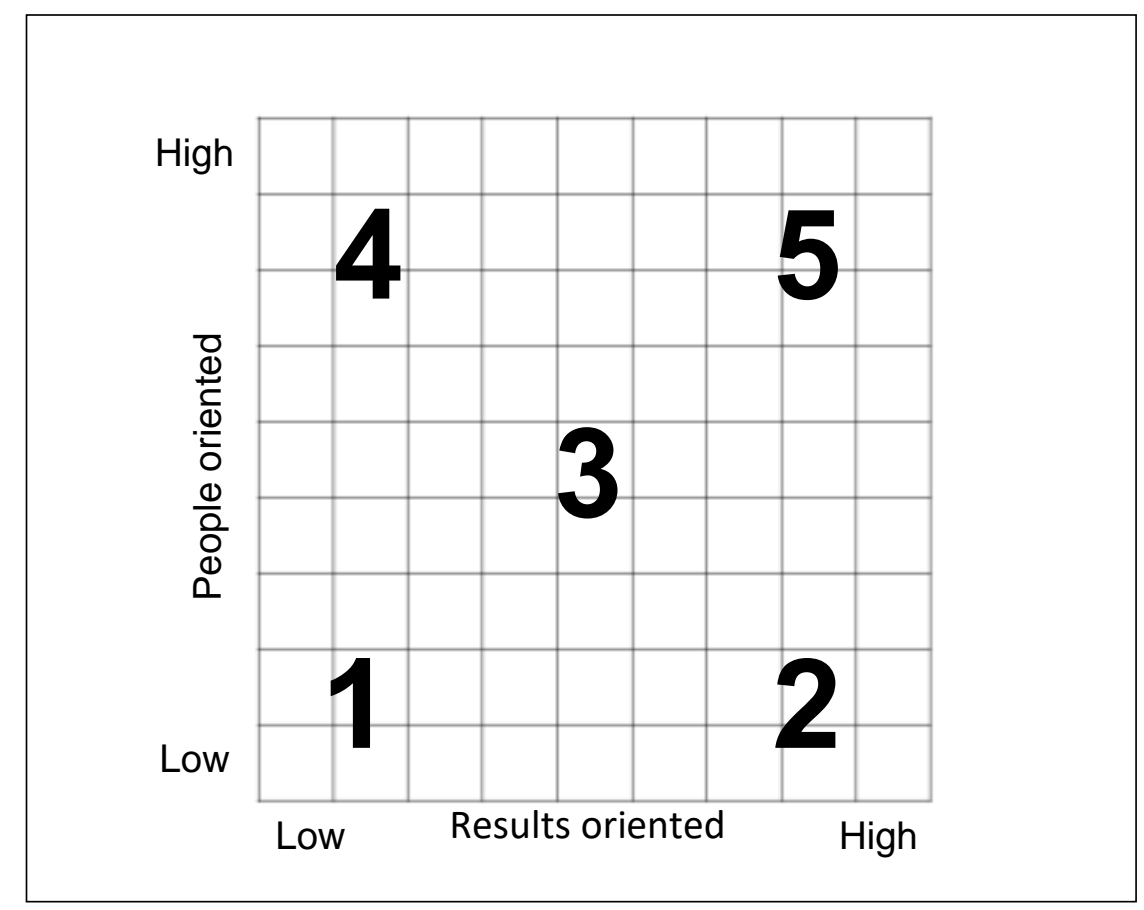


Figure 2: Managerial grid. Source: Blake and Mouton, 1964

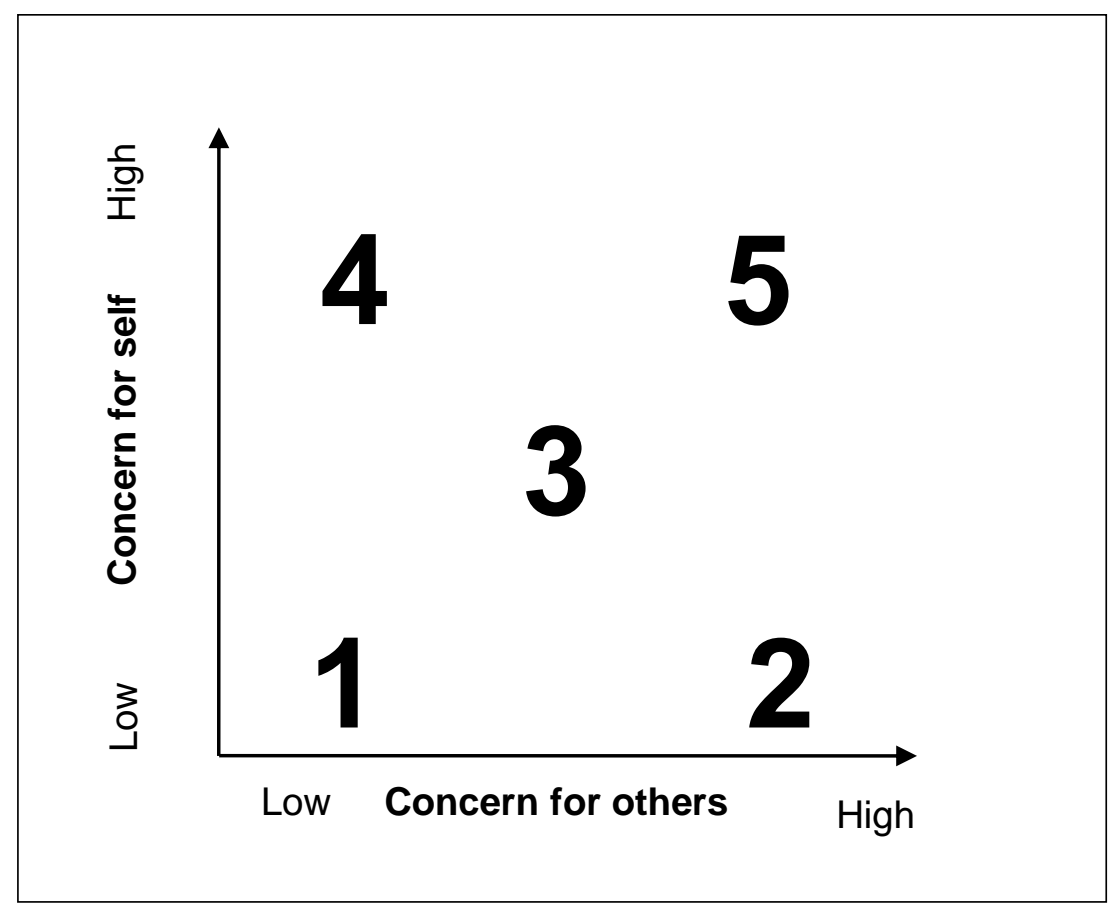

Figure 3: Dual concern model. Source: Pruitt \& Rubin, 1986.

Observe in Figure 2 the two-dimensions regarding results versus people orientation, as in the managerial grid (Blake \& Mouton, 1964), while in Figure 3, the two-dimensions include concerns for self, versus concern for others (Pruitt \& Rubin, 1986). In both cases, numbers 1 to 5 evidence a combination of high and low orientation/concerns nuances.

Based on these constructs, depicted in Figures 1-3, a more complex model is developed that includes all forms of negotiations (See Figure 4). Including both sets of matrices and models proved useful for a more detailed analysis of the negotiation dimensions.

Next, the Four-Type Negotiation matrix, as well as the theoretical rationale, are introduced. Then, methods and limitations, research design, and meta-analysis findings are presented. The managerial and conceptual implications, as well as the contribution to current epistemology in negotiation, are discussed. Finally, future research directions and potential applications are suggested.

\section{THE FOUR-TYPE NEGOTIATION MATRIX}

Figure 5 illustrates the four-type negotiation matrix. Observe the two-dimension matrix, involving two or more parties versus one or more issues negotiated, referring to four types of negotiation, such as (i) Type I: two-party, one issue; (ii) Type II: two-party, multiple issues; (iii) Type III: multipleparty, one issue, and (iv) Type IV: multiple-party, multiple issues. The four-type negotiation matrix accommodates all forms of negotiations, regardless of gender, age, business, industry, services, dispositional or circumstance factors. Notice Types I and III are distributive negotiations, and Types II and IV are integrative negotiations, according to Raiffa (1982), to be discussed in the next section. 


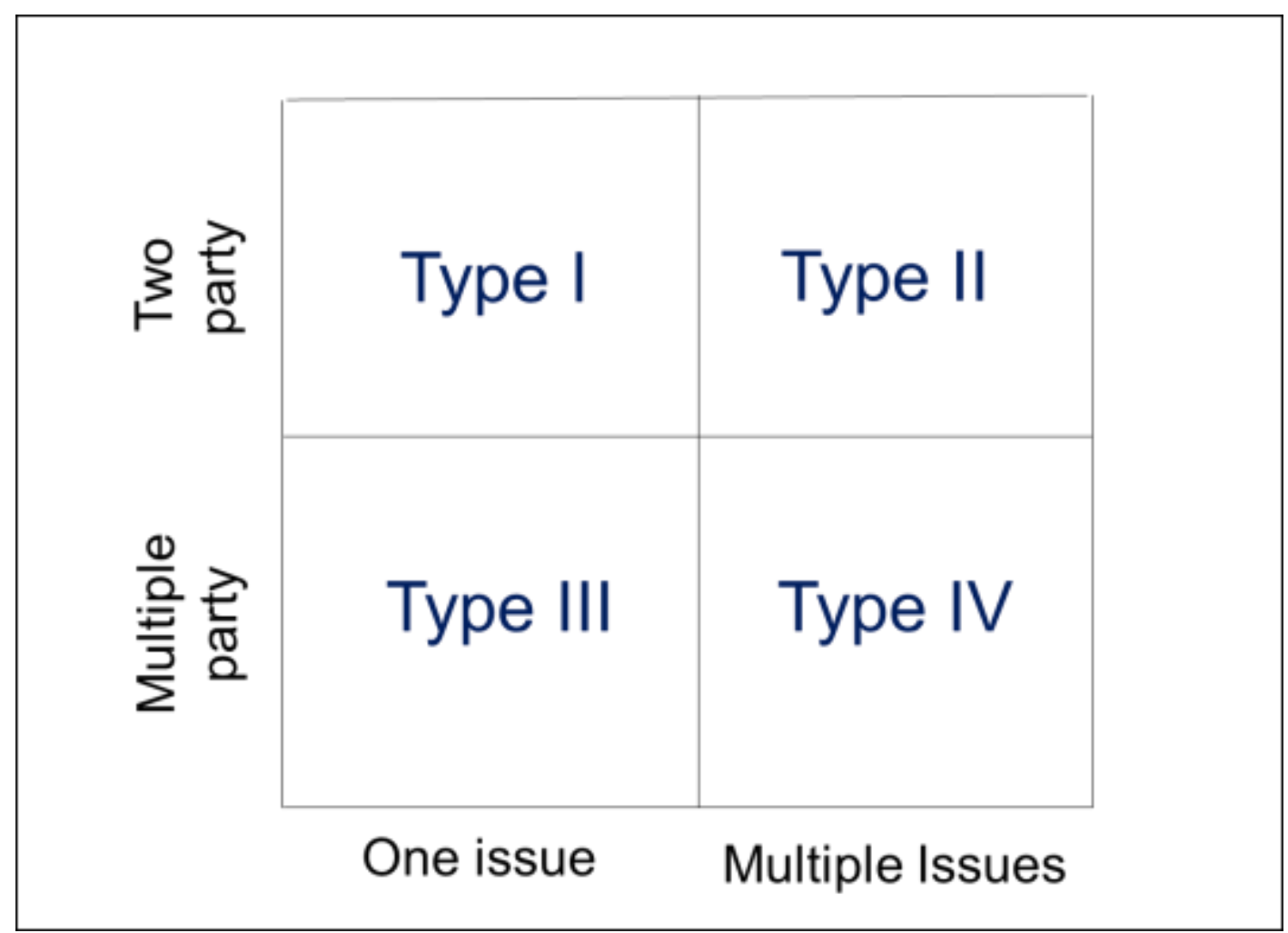

Figure 5: The Four-Type Negotiation Matrix

\section{THE MATRIX DEVELOPMENT - THEORETICAL BACKGROUND}

The Four-Type Negotiation Matrix is influenced by an extensive body of past research on (i) Negotiation (Raiffa, 1982; Fisher Ury and Patton, 1981; Sebenius, 1992; Ury, 2015; Susskind \& Field, 1996; Salacuse, 2008); (ii) Transactional negotiation between buyer and seller (Rinehart \& Page, 1992); (iii) Conflict management (Pruitt \& Rubin,1986; Thomas \& Killman, 1974, 2002); (iv) style leadership model (Blake \& Mouton, 1964); (v) Social value orientation (Liebrand \& McClintock, 1988; McClintock and Allison, 1989; Van Lange, Otten, De Bruin \& Joireman, 1997; Murphy, Ackermann \& Handgraaf, 2011), and the (vi) complexity of negotiation (Olekalns, M. \& Adair, W.L. (2013b), to name a few.

Negotiation is "a process of communication by which two or more persons seek to advance their individual interests through joint action." (Salacuse, 2006, p. 7). Also, "Negotiation is a process of communicating back and forth for the purpose of reaching a joint decision." (Fisher, Ury \& Patton, 1981, p. 20).

Howard Raiffa (1982), in his groundbreaking work, has defined distributive negotiation as "one single issue, such as money, is under contention" (p.33), and integrative negotiation as a "bargainingin which there are two parties and several issues to be negotiated" (p.131). Therefore, the current epistemology on negotiation is focused primarily on the number of issues being negotiated. Value creation before value distribution has been recommended for the aforementioned forms of 
negotiation, through the mutual gains approach (Susskind \& Cruikshank, 1987; Susskind \& Field, 1996).

Pruitt \& Rubin (1986), on the other hand, investigated dyadic conflicts through the two-dimensional Dual Concern Model (DCM - See Figure 3), later influencing works on social value orientation (Liebrand \& McClintock, 1988; McClintock and Allison, 1989; Van Lange, Otten, De Bruin \& Joireman, 1997; Murphy, Ackermann \& Handgraaf, 2011). Finally, DCM, however, is limited to dyadic, two-party negotiations, undirected to address multi-party negotiation issues. The same rationale is applied to the Thomas-Killman Instrument (Thomas \& Killman, 1974), Managerial Grid (Blake \& Mouton, 1964 - See Figure 3), and the Model of Transaction Negotiation (Rinehart \& Page, 1992). Both conceptual models are useful to address only two-party negotiations, leaving a research gap regarding multi-party negotiations, as illustrated in Figure 6:

\begin{tabular}{ccccc}
\hline Model & Authors & Year & $\begin{array}{c}\text { Two-party } \\
\text { interactions }\end{array}$ & $\begin{array}{c}\text { Multi-party } \\
\text { interactions }\end{array}$ \\
\hline Managerial Grid & $\begin{array}{c}\text { Blake and } \\
\text { Mouton } \\
\text { Pruitt \& Rubin }\end{array}$ & 1964 & $\bullet$ & - \\
Thal Concern Model & $\begin{array}{c}\text { Thomas \& } \\
\text { Killman }\end{array}$ & 1974,2002 & $\bullet$ & - \\
$\begin{array}{c}\text { Model of Transaction } \\
\text { Negotiation }\end{array}$ & & 1992 & $\bullet$ & - \\
\hline
\end{tabular}

Figure 6: theoretical background research gap

Observe in Figure 2 the research gap regarding the multi-party negotiations. Although the conceptual models are useful to address two-party negotiations, they leave a room to be explored regarding multiparties within a given negotiation. Finally, much attention is given to the number of issues negotiated: distributive negotiations versus integrative negotiations, respectively, one and multiple issues negotiated (Raiffa, 1982).

\section{METHODS AND RESEARCH LIMITATIONS}

This research combined multiple qualitative methods approach, such as qualitative meta-analysis, case study, with qualitative, extensive archival research. This article also compiled inductive reasoning with the interpretive approach, supported by Goffman's dramaturgical theory $(1959,1961)$. This section comprises the underlying assumptions, research limitations, and delimitations, as well as the research design adopted.

\section{Underlying assumptions and Research limitations}

The negotiation process investigated involves at least two parties (Dias, M. 2019, Raiffa, 1982; Fisher Ury and Patton, 1981; Sebenius, 1992; Ury, 2015; Susskind \& Field, 1996; Salacuse, 2008). 
Negotiations, where one party negotiates with oneself (Ury, 2015), are not the scope of the present work.

The negotiation process may evolve into other forms of negotiation. Figure 7 illustrates the continuum of conflict management and resolution approaches (More, 2003).

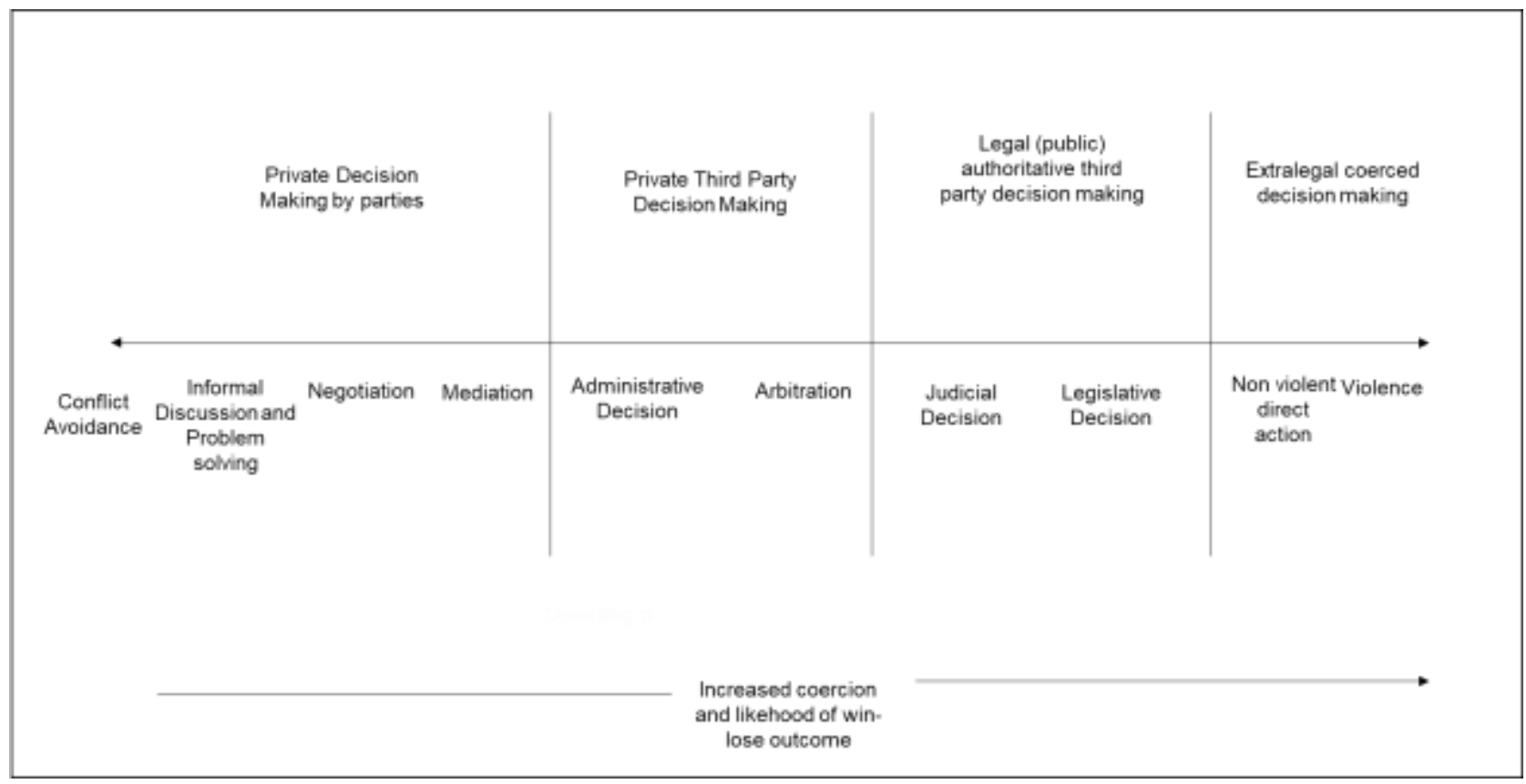

Figure 7: the continuum of conflict management and resolution approaches. Source: adapted from Moore, 2003, p.7.

Observe in Figure 7 that a negotiation process may evolve into a mediation, where a third party may join the negotiation, for instance, and vice-versa.

The number of parties in a negotiation may also vary during the negotiation. For instance, when a negotiation escalates into conflict, more parties tend to be involved in the upcoming negotiation process. A mediator or facilitator, for instance, may join an ongoing negotiation, turning a two-party into a multi-party negotiation (Pruitt \& Rubin, 1986, Moore, 2003).

The number of issues negotiated may also vary during the negotiation process through value creation, to enlarge the pie (Lax, 1985; Fisher, Ury, and Patton, 1981; Sebenius, 1992; Ury, 2015; Susskind \& Field, 1996).

This work is not limited to a specific form of negotiation, for instance, buyer-seller direct negotiation. Multi-party, multi-issues negotiations are investigated, regardless of the form of negotiation adopted. For example, in some cases, an agent negotiates on behalf of their counterparts (Dias, Ribeiro, and Lopes, 2019). 
The negotiation cases investigated are not limited to a single country. Also, this research investigated different sorts of businesses, industries, and services, for instance, (i) mining industry (Dias, M. \& Davila, 2018); aerospace industry (Cruz \& Dias, 2019, 2020; Dias, Lopes and Teles, 2020); (iii) civil works (Dias, M et al, 2017); (iv) public transportation (Dias, and Teles, 2018); (v) carmaker industry (Dias, Duzert, and Teles, 2018, Dias, 2017); (vii) retail business (Dias, et al, 2014); (viii) streaming video business (Dias and Navarro, 2017); (ix) civil aviation (Dias, 2020; Dias, Lopes and Teles, 2020; Dias, 2019); (x) cruise lines services (Dias \& Lopes, 2020), among others (see Table 1). The objective is to apply the qualitative conceptual model to all forms of negotiation. Therefore, in this research, there are no limitations in terms of gender, age, ethnicity, occupation, managerial level, level income, and education.

\section{Research Design}

$\mathrm{N}=50$ negotiation cases were investigated in the first set of cases. The findings were analyzed, and the model designed. Next, it was applied to a new set of random 50 negotiation cases, adopting the following criteria: (i) most of the negotiation cases should be recently published. Therefore, 70 percent of the negotiation cases selected were published between 2018-20. The matrix, however, can be applied to any negotiations, regardless their recency or relevance; (ii) any form of negotiation was accepted, such as different businesses, industries, or services were accepted; (iii) the same parameters should be used to both sets of data, totaling 100 articles investigated; (iv) the parameters adopted in this research are respectively: (a) two or multi-parties; (b) one or multiple issues negotiated; (c) distributive and integrative negotiations (Raiffa, 1982); (d) forms of negotiation, such as buyer-seller, supplier-client, between partners, one-time, repetitive negotiations, to name a few; (e) negotiation environment, such as industry, government, civil work, family business, retail business, cruise services, among others. Finally, (f) type of negotiation following the Four-Type Negotiation Matrix (See Figure 8). The case studies were first analyzed in separate to establish the content validity of the concepts and to improve the data collection.

The number of parties involved and the number of issues addressed in a given negotiation are two parameters not challenging to assess when investigating each negotiation case. Bias like Hawthorne effect or attribution bias may not be significant in this research.

\section{THE FOUR-TYPE NEGOTIATION MATRIX: FINDINGS}

The raw data were analyzed through content analysis. In the cases, the parties were identified according to their participation in the negotiation cases. Money-bargaining negotiations appeared in cases \#6, and \#12. The matrix classified all cases in the four types. Figure 8 shows the type of distribution among the $\mathrm{N}=50$ negotiation cases, as follows: 


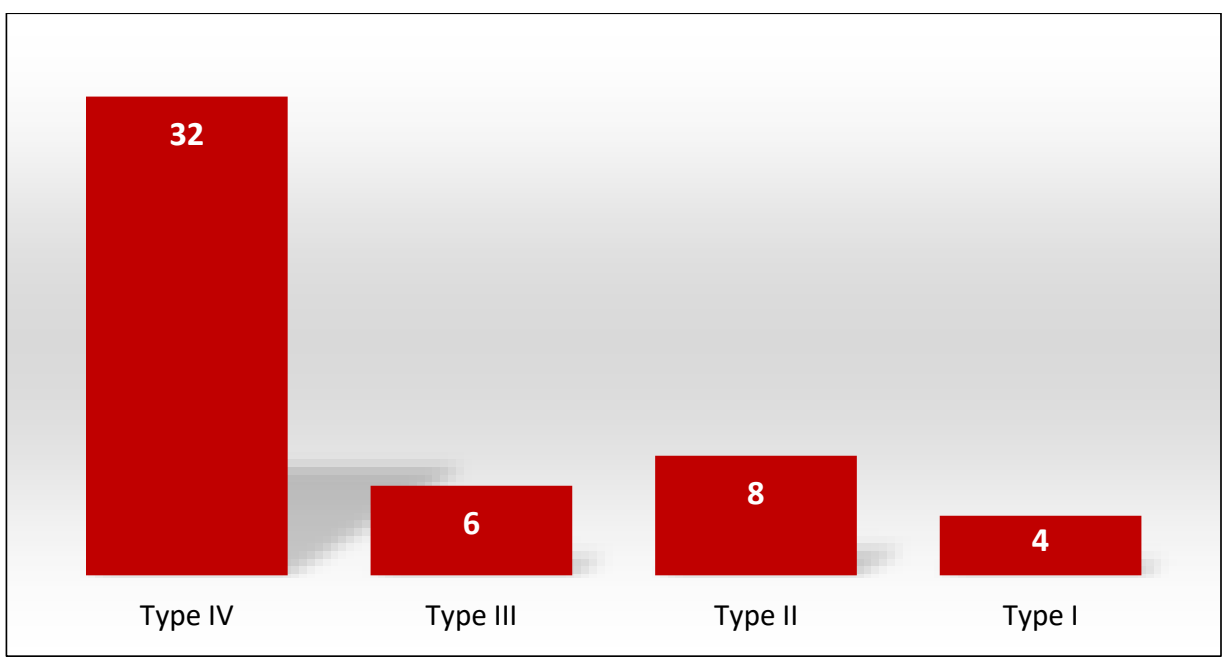

Figure 8: types distribution among the cases.

Observe in Figure 8 that 32 cases investigated reported Type IV negotiation (64 percent), which means multi-party, multi-issues negotiation. Such findings can be explained by the complexity of the negotiations investigated. For instance, in nine cases of the negotiations investigated (cases \#13, \#27, \#30, \#32, \#33, \#36, \#42, \#43, and \#49 - see Table 1), involved governments and multiple stakeholders (18 percent). On the contrary, in twelve negotiations (cases \#3, \#5, \#6, \#8, \#22, \#29, \#31, \#34, \#35, \#39, \#47, \#48) two-party negotiations, or Types I and II, were conducted (24 percent). Complexity also could be verified, according to the number of issues negotiated. Figure 9 illustrates the distribution of cases regarding the number of parties (left), and issues negotiated (right), as follows:

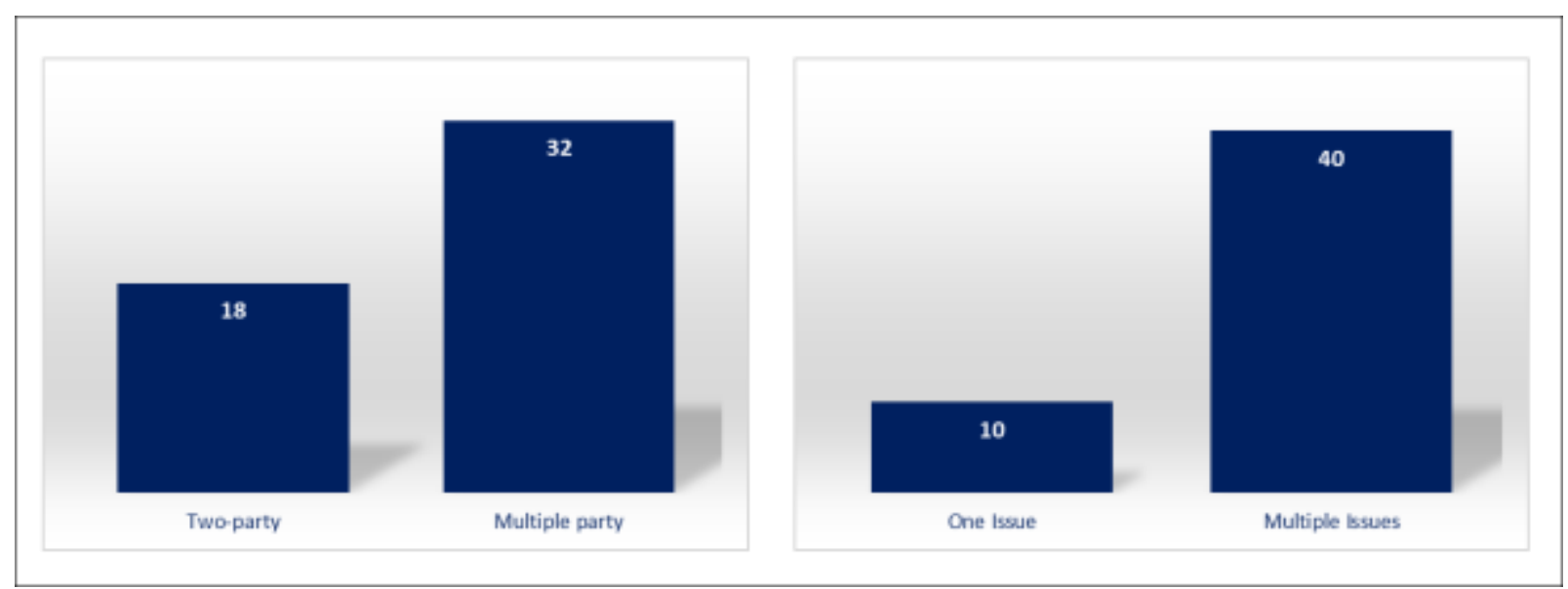

Figure 9: Distribution of the number of parties and the number of issues negotiated. 
Observe in Figure 9 that multiple party negotiations (64 percent), and multiple issues (80 percent) were the majority among the $\mathrm{N}=50$ cases investigated, while two-party (36 percent), and one issue negotiation (20 percent) were less frequent cases. One possible explanation to this finding, is the preference both from authors and editors to publish more complex cases, regarding the number of issues and the number of parties (multiple-party, multiple issues), than less complex cases (two-party, one issue). The complexity, however, discussed here is limited to the number of parties and issues negotiated. In some cases, apparently less complex, one-issue negotiations, can be hurtful and painful, and escalate into conflict. For instance, the custody of a child for divorced parents, can be a hurtful and complex negotiation, due to its nature. In this case, even if both parents agree freely upon the child custody (type I negotiation), it is only valid after the Court case appreciation, and only after a judge (third party) signs and files a decree of custody (type III negotiation).

Next, Table 1 illustrates the $\mathrm{N}=50$ negotiation cases investigated through qualitative meta-analysis (see the following pages). The negotiation cases involved different types of negotiation environments: (i) aerospace industry; (ii) mining industry; (iii) civil aviation; (iv) IT business; (v) copier and printing services; (vi) e-business; (vii) brewing industry; (viii) public transportation; (ix) nursing; (x) public administration; (xi) banking; (xii) fashion business; (xiii) carmaker industry; (xiv) rail transportation; (xv) streaming video industry; (xvi) cooperatives, or credit unions; (xvii) water distribution; (xviii) public health; (xix) pharmaceutical industry, (xx) vitiviniculture, and (xxi) civil works.

The cases investigated were both classified in distributive (20 percent), as well as integrative ( 80 percent) negotiations (Raiffa, 1982).

The Four-Type Negotiation Matrix was used successfully to classify all the $\mathrm{N}=50$ negotiation cases, as described in the research design section. As observed in Figure 8, the type IV negotiation appeared in 32 cases (64 percent), the most frequent negotiation type investigated. Table 1 illustrates the set of data studied, in the following pages: 
British Journal of Education (BJE)

Vol. 8, Issue 5, pp. 40-57, May 2020

Published by ECRTD- UK

Print ISSN: ISSN 2054-6351: Online ISSN: ISSN 2054-636X

Table 1: Table Meta-analysis of 50 negotiation cases

\begin{tabular}{|c|c|c|c|c|c|c|c|c|c|}
\hline \multirow{2}{*}{ \# } & \multirow{2}{*}{ Authors (Year) } & \multicolumn{2}{|c|}{ Parties } & \multicolumn{2}{|c|}{ Issues } & \multirow{2}{*}{$\begin{array}{c}\text { Form of } \\
\text { Negotiation }\end{array}$} & \multirow{2}{*}{ Environment } & \multirow{2}{*}{$\begin{array}{l}\text { Distributive/ } \\
\text { Integrative }\end{array}$} & \multirow{2}{*}{$\begin{array}{l}\text { Four-Type } \\
\text { Negotiation } \\
\text { Matrix }\end{array}$} \\
\hline & & $\begin{array}{c}\text { Two-party } \\
\text { negotiation }\end{array}$ & $\begin{array}{l}\text { Multi-party } \\
\text { negotiation }\end{array}$ & $\begin{array}{l}\text { One } \\
\text { issue }\end{array}$ & $\begin{array}{l}\text { Multiple } \\
\text { issues }\end{array}$ & & & & \\
\hline 1 & Cruz, B.S.; Dias, M. (2020) & & $\bullet$ & & $\bullet$ & B2B & Aerospace Industry & Integrative & Type IV \\
\hline 2 & Cruz, B.S.; Dias, M. (2020b) & & $\bullet$ & & $\bullet$ & $\mathrm{B} 2 \mathrm{C}$ & IT business & Integrative & Type IV \\
\hline 3 & Dias, M. (2012) & $\bullet$ & & & $\bullet$ & buyer-seller & Copier services & Integrative & Type II \\
\hline 4 & Dias, M. (2018) & & $\bullet$ & & $\bullet$ & cooperatives & cooperatives & Integrative & Type IV \\
\hline 5 & Dias, M. (2020) & $\bullet$ & & & $\bullet$ & $\mathrm{B} 2 \mathrm{C}$ & Brewing industry & Integrative & Type II \\
\hline 6 & Duzert \& Dias, (2017) & $\bullet$ & & $\bullet$ & & buyer-seller & E-business & Distributive & Type I \\
\hline 7 & Carvalho \& Dias (2019) & & $\bullet$ & $\bullet$ & & $\mathrm{B} 2 \mathrm{C}$ & E-business & Distributive & Type III \\
\hline 8 & Craveiro \& Dias, M. (2019) & $\bullet$ & & $\bullet$ & & peer-to-peer & Nursing & Distributive & Type I \\
\hline 9 & Dias, M. (2018c) & & $\bullet$ & & $\bullet$ & $\mathrm{B} 2 \mathrm{~B}$ & Public Transportation & Integrative & Type IV \\
\hline 10 & Dias, M. (2019) & & $\bullet$ & & $\bullet$ & Multiparty & Civil aviation & Integrative & Type IV \\
\hline 11 & Dias, M. (2019b) & & $\bullet$ & & $\bullet$ & Govenment & Executive Goverment & Integrative & Type IV \\
\hline 12 & Dias, M. (2019c) & & $\bullet$ & $\bullet$ & & Mediation & Banking & Distributive & Type III \\
\hline 13 & Dias \& Lopes (2019) & & $\bullet$ & & $\bullet$ & Government & Public Transportation & Integrative & Type IV \\
\hline 14 & Dias, M. (2019d) & & $\bullet$ & $\bullet$ & & Debt collection & Banking & Distributive & Type III \\
\hline 15 & Dias, M. (2020b) & & $\bullet$ & & $\bullet$ & Multiparty & Civil aviation & Integrative & Type IV \\
\hline 16 & Dias, M. (2020c) & & $\bullet$ & & $\bullet$ & Multiparty & Civil aviation & Integrative & Type IV \\
\hline 17 & Dias et al. 2014 & & $\bullet$ & & $\bullet$ & Family business & Fashion Business & Integrative & Type IV \\
\hline 18 & Dias et al. 2015 & & $\bullet$ & & $\bullet$ & Family business & Fashion Business & Integrative & Type IV \\
\hline 19 & Dias \& Navarro (2017) & & $\bullet$ & & $\bullet$ & B2C & Streaming business & Integrative & Type IV \\
\hline 20 & Dias, M., (2016). & & $\bullet$ & & $\bullet$ & civil works & Public administration & Integrative & Type IV \\
\hline 21 & Dias, Navarro, Valle, (2014) & & $\bullet$ & $\bullet$ & & merger & carmaker industry & Distributive & Type III \\
\hline 22 & Dias \& Aylmer (2018) & $\bullet$ & & & $\bullet$ & $\begin{array}{c}\text { generational } \\
\text { issues }\end{array}$ & workplace & Integrative & Type II \\
\hline 23 & Nauges \& Thomas (2000) & & $\bullet$ & & $\bullet$ & civil works & Water distribution & Integrative & Type IV \\
\hline 24 & Davila \& Dias (2018) & & $\bullet$ & $\bullet$ & & Family business & Mining & Distributive & Type III \\
\hline 25 & Dias, Teles and Pilatti, K. (2018) & & $\bullet$ & & $\bullet$ & Govenment & Executive Goverment & Integrative & Type IV \\
\hline
\end{tabular}

Note: to be continued in the next page 
British Journal of Education (BJE)

Vol. 8, Issue 5, pp. 40-57, May 2020

Published by ECRTD- UK

Print ISSN: ISSN 2054-6351: Online ISSN: ISSN 2054-636X

Meta-analysis of 50 negotiation cases (continuation)

\begin{tabular}{|c|c|c|c|c|c|c|c|c|c|}
\hline \multirow{2}{*}{ \# } & \multirow{2}{*}{ Authors (Year) } & \multicolumn{2}{|c|}{ Parties } & \multicolumn{2}{|c|}{ Issues } & \multirow{2}{*}{$\begin{array}{c}\text { Form of } \\
\text { Negotiation }\end{array}$} & \multirow{2}{*}{ Environment } & \multirow{2}{*}{$\begin{array}{l}\text { Distributive/ } \\
\text { Integrative }\end{array}$} & \multirow{2}{*}{$\begin{array}{c}\text { Four-Type } \\
\text { Negotiation } \\
\text { Matrix }\end{array}$} \\
\hline & & $\begin{array}{c}\text { Two-party } \\
\text { negotiation }\end{array}$ & $\begin{array}{l}\text { Multi-party } \\
\text { negotiation }\end{array}$ & $\begin{array}{l}\text { One } \\
\text { issue }\end{array}$ & $\begin{array}{l}\text { Multiple } \\
\text { issues }\end{array}$ & & & & \\
\hline 26 & Dias \& Teles (2019) & & $\bullet$ & & $\bullet$ & $\mathrm{B} 2 \mathrm{C}$ & Brewing Industry & Integrative & Type IV \\
\hline 27 & Dias \& Teles (2018) & & $\bullet$ & & $\bullet$ & Government & Public Transportation & Integrative & Type IV \\
\hline 28 & Susskind \& Field (1996) & & $\bullet$ & & $\bullet$ & Multiparty & Environment & Integrative & Type IV \\
\hline 29 & Rinehart \& Page (1992) & $\bullet$ & & $\bullet$ & & Buyer-seller & Retail business & Distributive & Type I \\
\hline 30 & Dias et al. (2014) & & $\bullet$ & & $\bullet$ & Government & Civil Rights & Integrative & Type IV \\
\hline 31 & Dias \& Duzert (2016) & $\bullet$ & & & $\bullet$ & merger & carmaking industry & Integrative & Type II \\
\hline 32 & Dias, Lopes (2019) & & $\bullet$ & & $\bullet$ & Government & Public Transportation & Integrative & Type IV \\
\hline 33 & Dias, Navarro and Valle (2013) & & $\bullet$ & & $\bullet$ & Government & carmaking industry & Integrative & Type IV \\
\hline 34 & Dias, Teles and Duzert (2018) & $\bullet$ & & & $\bullet$ & $\mathrm{B} 2 \mathrm{~B}$ & aerospace industry & Integrative & Type II \\
\hline 35 & Dias, Alves and Pezzella (2016) & $\bullet$ & & & $\bullet$ & $\mathrm{B} 2 \mathrm{C}$ & vitiviniculture & Integrative & Type II \\
\hline 36 & Dias \& Aylmer, 2018 & & $\bullet$ & & $\bullet$ & Government & social security reform & Integrative & Type IV \\
\hline 37 & Dias \& Navarro (2018) & & $\bullet$ & $\bullet$ & & Mediation & Mediation case & Distributive & Type III \\
\hline 38 & $\begin{array}{l}\text { Krein, Streh, Vilhena and Dias } \\
(2018)\end{array}$ & & $\bullet$ & & $\bullet$ & $\mathrm{B} 2 \mathrm{C}$ & Agriculture & Integrative & Type IV \\
\hline 39 & Dias \& Mori (2018) & $\bullet$ & & $\bullet$ & & nursing & Obstetric violence & Distributive & Type I \\
\hline 40 & Dias (2020) & & $\bullet$ & & $\bullet$ & $\mathrm{B} 2 \mathrm{C}$ & Craft brewing industry & Integrative & Type IV \\
\hline 41 & Dias \& Falconi (2018) & & $\bullet$ & & $\bullet$ & $\mathrm{B} 2 \mathrm{C}$ & Craft brewing industry & Integrative & Type IV \\
\hline 42 & Dias \& Lopes (2019) & & $\bullet$ & & $\bullet$ & Government & Rail transportation & Integrative & Type IV \\
\hline 43 & Dias \& Lopes (2020) & & $\bullet$ & & $\bullet$ & Government & Public Health & Integrative & Type IV \\
\hline 44 & Dias, Teles Duzert (2018) & & $\bullet$ & & $\bullet$ & $\mathrm{B} 2 \mathrm{~B}$ & Aerospace industry & Integrative & Type IV \\
\hline 45 & Dias, Alambert (2018) & & $\bullet$ & & $\bullet$ & $\mathrm{B} 2 \mathrm{C}$ & Cooperatives & Integrative & Type IV \\
\hline 46 & Dias \& Teles (2019) & & $\bullet$ & & $\bullet$ & $\mathrm{B} 2 \mathrm{C}$ & Brewing industry & Integrative & Type IV \\
\hline 47 & $\operatorname{Lax}(1985)$ & $\bullet$ & & & $\bullet$ & buyer-seller & buyer-seller & Integrative & Type II \\
\hline 48 & Levy, S., \& Gvili (2020) & $\bullet$ & & & $\bullet$ & buyer-seller & buyer-seller & Integrative & Type II \\
\hline 49 & Kölling, M. (2015) & & $\bullet$ & & $\bullet$ & Government & Public Administration & Integrative & Type IV \\
\hline 50 & $\begin{array}{l}\text { Hosken,Schmidt \& Weinberg } \\
(2020)\end{array}$ & & $\bullet$ & & $\bullet$ & B2B & Pharmaceutical & Integrative & Type IV \\
\hline
\end{tabular}




\section{IMPLICATIONS AND DISCUSSION}

The objective of this research was to develop a negotiation model that encompassed all types of negotiations, regardless of environments, circumstances, gender, age, net income, and level of education, which could be applied to all negotiation cases. Evidence showed that the more complex the negotiation is, the higher the type of negotiation. Evidence also pointed out that the negotiations are interchangeable, which means that during the negotiation process, if a new player joins an ongoing one-issue negotiation (Type I), it becomes a Type III negotiation (multiple-party, one issue). Alternatively, if new issues are added to a two-party negotiation with one issue (Type I), it becomes a Type III negotiation.

Consider the following example: a couple decides to buy an apartment. At this moment, there are two parties, dealing with one issue (the apartment), therefore, Type I negotiation. Suppose the couple deepens the conversation about the best-case scenario for them regarding the apartment location, infrastructure, school for kids, proximity to shopping center, among other issues. The negotiation moves from Type I to Type II (two-parties, multiple issues). Next, the couple finds an apartment, and both have to negotiate with a real estate broker. Then, the negotiation moved from Type II to Type III (multiple-parties, one issue, still the apartment (one issue). Finally, the real estate broker and the couple start negotiating on the specifics, payment terms, and contract collaterals. Then, the negotiation moved from Type III to Type IV (multiple-party, multiple issues). Therefore, one implication is clear: the negotiation may evolve in degrees of Complexity, depending on the number of parties and issued involved. Susskind and Cruikshank (2006) report a negotiation with 95 parties, arguing that it is complicated to reach a consensus basis with too many parties. The same authors have created an approach to maximize mutual gains: the mutual gains approach that consists in four negotiation stages: (i) preparation (ii) value creation (iii) value distribution, and (iv) follow through (1987).

The findings substantiate the importance of value creation before value distribution through the mutual gains approach (Susskind and Cruikshank (1987). According to Dias (2016), "The past and present researchers drew a great deal of attention in how to encourage the parties, moving from inaction to problem-solving, and promote mutual gains instead of maximization of one or the other player's utility." (p.38) Following Van Lange, Otten, De Bruin \& Joireman (1997), there are two alternatives: to maximize oneself or mutual gains in a negotiation.

The parties within the negotiation process usually exchange information, including costs, desired levels of services, volumes of operations, legal terms, norms, regulations, delivery terms and deadlines, and material availability. Understanding the parties' interests, nature (psychological, material, and procedural), as proposed by Moore (2006), can help both to achieve better deals. Value creation also implies new options (issues) creation (Susskind and Cruikshank, 2006). Therefore, value creation implies moving from Type I into Type II negotiation and from Type III into Type IV negotiation (see Figure 5).

No matter the degree of coercion in escalating conflicts, according to Moore (2006), as depicted in Figure 6, the four-type negotiation matrix is helpful to provide negotiators a perspective of 
negotiation status, and thus help to plan the next steps, to better a deal or to solve a conflict, for instance.

However, in a competitive scenario, the culture of value creation is more difficult to be implemented than in a collaborative environment. Therefore, distributive strategies of negotiation are recommended for competitive scenarios. Conversely, integrative strategies are most suited for cooperative scenarios (Rinehart \& Page, 1992). Hence, in a competitive scenario, the implication is related to additional difficulties regarding negotiations moving from type I into type II, and from type III into type IV.

Companies that face competitive negotiations tend to find more difficult in the buyer-seller negotiation process (Rinehart \& Page, 1992). Also, negotiations with multiple parties and one issue (type III negotiation) may tend to be more difficult, as the number of parties increase, as a possible study implication.

Finally, one sad example is the distribution of food in refugee camps. Sometimes a bottle of water is disputed among many refugees (multiple parties, one issue - type III negotiation). In such extreme, competitive scenario, the continuous stress, starvation, food scarcity leads to competition. In such cases, the survival instinct speaks louder than human cooperation.

\section{Future research directions}

This research addressed all types of negotiations in which two parties are negotiating at least one issue. Future research should address potential differences between parties, regarding their tend for competition or cooperation, and to assess the impact of the negotiation environment on the interchangeability of negotiation types as proposed by the four-type negotiation matrix. Finally, future research should investigate the best optimization strategies for all four types of negotiation individually, aiming at improving mutual agreements.

\section{REFERENCES}

Blake, R.R. \& Mouton, J.S. (1964). The Managerial Grid. Houston, TX: Gulf Publishing.

Carvalho, M.; Dias, M. (2019). Consumer Purchase-Behavior: Potential Markets In Argentina For Brazilian E-Book Retailers. British Journal of Marketing Studies 7(1), 1-25. doi: 10.13140/RG.2.2.30371.50728

Craveiro \& Dias, M. (2019). Case on Brazilian Public Health Information System. Global Scientific Journals, 7(10), 1-11. doi: 10.11216/gsj.2019.10.27963

Cruz, B.S.; Dias, M. (2020). Crashed Boeing 737-MAX: Fatalities or Malpractice? Global Scientific Journals, 8(1), 2615-2624. doi: 10.11216/gsj.2020.01.34917

Cruz, B.S.; Dias, M. (2020b). Does Digital Privacy Really Exist? When the Consumer Is the Product. Saudi Journal of Engineering and Technology, 5(2), 0-4. doi: 10.36348/sjet.2020.v05i02.00X

Dias, M., (2016). Factors Influencing the Success of Business Negotiations in the Brazilian Culture (Doctoral Thesis). ESC Rennes School of Business, France. doi: 10.13140/RG.2.2.18660.22407 
British Journal of Education (BJE)

Vol. 8, Issue 5, pp. 40-57, May 2020

Published by ECRTD- UK

Print ISSN: ISSN 2054-6351: Online ISSN: ISSN 2054-636X

Dias, M. (2012). Two Case Studies on how to Deal Effectively with Fixed plus Variable Costs Contracts. International Journal of Business and Management Studies, 1(3), 505-515. doi: 10.6084/m9.figshare.7832288

Dias, M. (2018) Evolution of Cooperative Societies in Brazil. International Journal of Community and Cooperative Studies, 6(4), 1-11. doi: 10.6084/m9.figshare.7834688

Dias, M. (2018b). Heineken Brewing Industry in Brazil. International Journal of Management, Technology and Engineering, 8(9), 1304-1310. doi:16.10089/IJMTE2156

Dias, M. (2018c). Light Vehicle Vehicle in Rio de Janeiro: Alternative to Public Transportation in Brazil? Australian Journal of Science and Technology. 2(4), 187-193. doi: 10.6084/m9.figshare.7833362

Dias, M. (2019). Air Passenger Transportation in Brazil. Global Scientific Journals. 7(10), 310-317. doi: 10.13140/RG.2.2.26800.71688

Dias, M. (2019b). Brazilian Legislation on Executive Power: Provisory or Permanent Measures? Scholars International journal of Law, Crime and Justice, 2(10), 336-341. doi: 10.36348/SIJLCJ.2019.v02i10.007

Dias, M. (2019c). Is it Worth Competing at the Bargaining Table? Global Scientific Journals, 7(9), 1-14. doi: 10.13140/RG.2.2.11557.45288

Dias, M. (2019). People, Process, and Substance: Current Definitions on Negotiation. International Journal of Commerce and Economics, 1 (3), 1-9. doi: 10.13140/RG.2.2.15836.95360

Dias, M. (2019d). Teaching Materials: Role Play Simulation On Individual Business Debt Collection In Brazil. Global Scientific Journals, 7(8), 844-859. doi: 10.11216/gsj.2019.08.26134

Dias, M. (2020b). Air Transportation in Brazil: São Paulo Congonhas Airport. Global Scientific Journals, 8(2), 3244-3252. doi: 10.11216/gsj.2020.02.35259

Dias, M. (2020c). Case on Domestic Air Passenger Transport Market in Brazil. The Journal of Middle East and North Africa Sciences, 6(4), 5-9. doi: 10.13140/RG.2.2.12166.73280

Dias, M. (2020). Fatality, Malpractice, or Sabotage? Case on Craft Beer Poisoning in Minas Gerais, Brazil. East African Scholars Multidisciplinary Bulletin, 3(1), 26-31. doi: 10.36349/EASJMB.2020.v03i01.04

Dias, M. et al. (2014). Dudalina S/A: Case Study on How to Overcome Succession Barriers on a Brazilian Family Business. Business and Management Review, 3(12), 217-229. doi: 10.6084/m9.figshare.7834748

Dias, M. et al. (2015). Brazilian Fashion Business Dudalina S/A: Case Revisited. International Journal of Business and Management Studies, 4(1), 11-24. doi: 10.6084/m9.figshare.7834730

Dias, M. et. al. (2014). Domestic Workers' Rights in Brazil: Improvement of Labor Regulation. Humanities and Social Sciences Review, 3(2), 9-21. doi: 10.6084/m9.figshare.7834745

Dias, M. et. al. (2014). FIAT and Chrysler in Brazil: Anatomy of an Alliance. International Journal of Business and Management Studies, 3(1), 1-13. doi: 10.6084/m9.figshare.7834739

Dias, M., (2016). São Francisco River Transposition Civil Work: Challenges to the Brazilian Economy. The International Journal of Business \& Management. 4(12), 65-70. doi: 10.6084/m9.figshare.7834724

Dias, M., and Aylmer, R. (2018) Are the generational interactions in the Brazilian workplace different from other countries? Global Journal of Human Resource Management, 6(1), 9-25. doi: 10.6084/m9.figshare.7834634 
British Journal of Education (BJE)

Vol. 8, Issue 5, pp. 40-57, May 2020

Published by ECRTD- UK

Print ISSN: ISSN 2054-6351: Online ISSN: ISSN 2054-636X

Dias, M., Duzert, Y. (2016). Fiat Chrysler Automobiles in Brazil: Alliance Consolidated. The International Journal of Business \& Management, 4(2), 160-166. doi: 10.6084/m9.figshare.7834733

Dias, M., Falconi, Davi. (2018), The Evolution of Craft Beer Industry in Brazil. Journal of Economics and Business, 1(4), 618-626. doi: 10.31014/aior.1992.01.04.55

Dias, M., Lopes, R. (2019). Rail Transportation in Brazil: Challenges and Opportunities. Arabian Journal of Business and Management Review (Kuwait Chapter), 8(4), 40-49. doi: 10.13140/RG.2.2.27687.70568

Dias, M., Lopes, R. (2020) Will the COVID-19 Pandemic Reshape our Society? EAS Journal of Humanities and Cultural Studies (EAS J Humanit Cult Stud). 2(2), 93-97. doi: 10.36349/EASJHCS.2020.V02I02.013

Dias, M., Lopes, R. (2020). Air Cargo Transportation in Brazil. Global Scientific Journals. 8(2), 4180-4190.doi:10.13140/RG.2.2.30820.32648

Dias, M., Lopes, R. (2020). Case on Cruise Ship Failure Services: Onboard. Arabian Journal of Business and Management Review (Kuwait Chapter), 9(1), 10-19 doi: 10.13140/RG.2.2.14280.26887

Dias, M., Lopes, R., Teles, A. (2020) Could Boeing 737 MAX Crashes be Avoided? Factors that Undermined Project Safety. Global Scientific Journals, 8(4), 187-196. doi: $10.11216 / g s j .2020 .04 .38187$

Dias, M., Lopes, R., Teles, A. (2020) Will Virtual Replace Classroom Teaching? Lessons from Virtual Classes via Zoom in the Times of COVID-19. Journal of Advances in Education and Philosophy, 4(5), 208-213. doi: 10.36348/jaep.2020.v04i05.004

Dias, M., Navarro, R. (2018). Is Netflix Dominating Brazil? International Journal of Business and Management Review. 6, No.1, 19-32, January 2018. ISSN: 2052-6407. doi: 10.6084/m9.figshare.7834643

Dias, M., Navarro, R.; Valle, A. (2013). BMW and Brazilian Federal Government: Enhancing the Automotive Industry Regulatory Environment. International Journal of Arts and Sciences, 6(2), 551-567. doi: 10.6084/m9.figshare.7834742

Dias, M., Teles, A. Duzert, Y. (2018) Did Embraer Succeed In Adopting The International Financial Reporting Standards (IFRS) In Brazil? European Journal of Accounting, Auditing and Finance Research, 6(2), 51-62. doi: 10.6084/m9.figshare.7834637

Dias, M., Teles, A., Duzert, Y. (2018) Will Boeing Succeed with the Embraer Acquisition Operation, Despite the Brazilian Federal Government Golden Share Veto? International Journal of Business and Management Review, 6(2), 55-64. doi:10.6084/m9.figshare.7834718

Dias, M.; Alves, H.; Pezzella, M. (2016) São Francisco Valley: Vitiviniculture Activities in the Brazilian Unthinkable Semiarid Climate and its Challenges. International Journal of Business and Management Review 4(10), 1-13. doi: 10.6084/m9.figshare.7834727

Dias, M.; Aylmer, R. (2018) Is the Brazilian Civil Service reform about to succeed? Global Journal of Political Science and Administration, 6(2), 13-25. doi: 10.6084/m9.figshare.7834694

Dias, M.; Davila Jr., E. (2018) Overcoming Succession Conflicts in a Limestone Family Business In Brazil. International Journal of Business and Management Review, 6(7), 58-73. doi: 10.6084/m9.figshare.7834703 
British Journal of Education (BJE)

Vol. 8, Issue 5, pp. 40-57, May 2020

Published by ECRTD- UK

Print ISSN: ISSN 2054-6351: Online ISSN: ISSN 2054-636X

Dias, M.; Duzert, Y. (2017). Teaching Materials: Role Play Simulation on E-Business Negotiation. European Journal of Training and Development Studies, 4(3), 1-15. doi: 10.6084/m9.figshare.7834655

Dias, M.; Duzert, Y., Teles, A. (2018). Boeing, Brazilian Federal Government, And Embraer: Golden Share Veto and The Anatomy of a Joint Venture. International Journal of Business and Management Studies, 7(2), 71-80. doi: 10.13140/RG.2.2.14972.18563

Dias, M.; Krein, J.; Streh, E.; Vilhena, J. B. (2018) Agriculture Cooperatives in Brazil: Cotribá Case. International Journal of Management, Technology and Engineering, 8(12). doi:16.10089.IJMTE.2018.V8I12.17.2243

Dias, M.; Mori, V. (2018). Obstetric Violence in Brazil: an Integrated Case Study. International Journal of Nursing, Midwife and Health Related Cases, 4(6), 20-28. doi: 10.6084/m9.figshare.7834274

Dias, M.; Ramos, M. (2018). Credit Cooperatives in Brazil. International Journal of Science and Research (IJSR), 7(10), 598-603. doi: 10.21275/ART20191901

Dias, M.; Ribeiro, Ana Paula; Lopes, Raphael (2019). When customers do not pay: A Winning Negotiation Case in Brazil. Journal of Economics and Business, 2(2), 431-447. doi: 31014/aior.1992.02.02.99

Dias, M.; Teles, A.; Pilatti, K. (2018) The Future of Privatization in Brazil: Regulatory and Political Challenges. Global Journal of Politics and Law Research, 6(2), 32-42. doi: 10.6084/m9.figshare.7834709

Dias, M.; Teles, Andre (2018). Agriculture Cooperatives in Brazil and the Importance for The Economic Development. International Journal of Business Research and Management, 9(2), 72-81. doi: 10.6084/m9.figshare.7832354

Dias, M.; Teles, Andre (2018). From Animal Traction to LRV: Public Rail Transportation in Rio de Janeiro. International Journal of Science and Research, 7(11), 765-770. doi: 10.21275/ART20192818

Dias, M.; Teles, Andre (2019). Facts and Perspectives on Craft Brewing Industry in Brazil. International Journal of Management, Technology and Engineering, 9(2), 1020-1028. doi:16.10089/IJMTE.2019.V9I21.18.28020

Elfenbein (2013). Individual differences in negotiation. In: Olekalns, M, and Adair, W.L. (eds.) Handbook of Research in Negotiation. UK: Edward Elgar Publishing Limited, pp. 25-45.

Fisher, R. Ury, W. and Patton, B (Editor). (1981). Getting to Yes: Negotiating an Agreement without Giving in. US: Random House.

Goffman, E (1959). The Presentation of Self in Everyday Life. New York: Doubleday.

Goffman, E. (1961). Encounters: Two Studies in the sociology of interaction. Indianapolis: The Bobbs-Merrill Company.

Grbich, C. (2013). Qualitative data analysis: An introduction (2nd Ed.). London, UK: Sage.

Griesinger, D. W. \& Livingston, J. W. (1973). Toward a model of interpersonal motivation in experimental games. Behavioral Science, 18(3), 173-188.

Hosken, D., Schmidt, D., \& Weinberg, M. C. (2020). Any Willing Provider and Negotiated Retail Pharmaceutical Prices. The Journal of Industrial Economics, 68(1), 1-39.

Kölling, M. (2015). Subnational Governments in the Negotiation of the Multiannual Financial Framework 2014-2020: The Case of Spain. Regional \& Federal Studies, 25(1), 71-89. 
British Journal of Education (BJE)

Vol. 8, Issue 5, pp. 40-57, May 2020

Published by ECRTD- UK

Print ISSN: ISSN 2054-6351: Online ISSN: ISSN 2054-636X

Lax, David. (1985) Optimal Search in Negotiation Analysis. The Journal of Conflict Resolution, 29(3), 456-472.

Levy, S., \& Gvili, Y. (2020). Online shopper engagement in price negotiation: the roles of culture, involvement and eWOM. International Journal of Advertising, 39(2), 232-257.

Liebrand, W.B.G. \& McClintock, C. G. (1988). The ring measure of social values: A computerized procedure for assessing individual differences in information processing and social value orientation. European Journal of Personality, 2(3), 217-230.

McClintock, C. G., \& Allison, S. T. (1989). Social value orientation and helping behavior. Journal of Applied Social Psychology, 19 (3), 353-362.

Moore, C.W. (2003). The Mediation Process: Practical Strategies for Resolving Conflict. San Francisco (California) and London: Jossey-Bass.

Murphy, R.O. \& Ackermann, K. A. (2014) Social Value Orientation: Theoretical and Measurement Issues in the Study of Social Preferences. Perspectives in Social Psychology Review, 18(2), 13-41.

Murphy, R.O., Ackermann, K.A. and Handgraaf, M.J.J. (2011). Measuring Social Value Orientation. Judgment and Decision Making, 6(8), 771-781.

Nauges, C., \& Thomas, A. (2000). Privately operated water utilities, municipal price negotiation, and estimation of residential water demand: the case of France. Land Economics, 76(1), 6885.

Olekalns, M. \& Adair, W.L. (2013b). The Complexity of negotiation: from the individual to the context and what lies in between. In: Olekalns, M. \& Adair, W.L. (eds.) Handbook of Research in Negotiation. Cheltenham, UK: Edward Elgar Publishing Limited, 25-45.

Paradela, V.; Dias, M.; Sampaio, D.; Plácido, E.; Fernandes, G. (2019). Best Managerial Practices in Retail Business in Juiz De Fora-MG. International Journal of Management, Technology and Engineering, 9(3), 3521-3538. doi:16.10089.IJMTE/2019.V9I3.19.27864

Pruitt, D.G. \& Rubin, J.Z. (1986). Social conflict: Escalation, Stalemate, and Settlement. New York: McGraw-Hill.

Raiffa, Howard. (1982). The Art and the Science of Negotiation: How to Resolve Conflicts and get the Best out of Bargaining. Cambridge, MA: Harvard University Press.

Rinehart, L. and Page, T. (1992) The Development and Test of a Model of Transaction Negotiation. Journal of Marketing, 56(4), 18-32.

Salacuse, J. (2008). Seven Secrets for Negotiating with Government: How to Deal with Local, State, National, Or Foreign Governments - And Come Out Ahead. New York: Amacom.

Sebenius, J. (1992). Negotiation Analysis: A Characterization and Review. Management Science, 38(1), 18-38.

Soares, C.; Magalhães, M.; Barroca, J.; Dias, M. (2020). Investment Capital Budget Method Oriented to Project Management. Global Scientific Journals, 8(3), 855-870. doi: 10.11216/gsj.2020.03.37108

Susskind, L. and P. Field (1996), Dealing with an Angry Public: The Mutual Gains Approach to Resolving Disputes. New York: Free Press.

Susskind, Lawrence; Cruikshank, Jeffrey. (1987). Breaking the Impasse: Consensual Approaches to Resolving Public Disputes. New York, NY: Basic Books.

Susskind, Lawrence; Cruikshank, Jeffrey (2006) Breaking Roberts Rules: The New Way to Run Your Meeting, Build Consensus, and Get Results. New York: Oxford Press. 
Thomas, K. W., \& Kilmann, R. H. (1974). Thomas-Kilmann Conflict Mode Instrument. Mountain View, CA: Xicom.

Thomas, Kenneth \& Gail F. (2002). Introduction to conflict management: improving performance using the TKI. Mountain View, California: CPP Inc.

Ury, W. (2015). Getting to Yes with Yourself and Other Worthy Opponents.MA: Harper Collins.

Van Lange, P.A.M., Otten, W., De Bruin, E.M.N., \& Joireman, J.A. (1997). Development of Prosocial, Individualistic, and Competitive Orientations: Theory and Preliminary Evidence. Journal of Personality and Social Psychology, 73(4), 733-746. 